\title{
Analisis Perbandingan Model Prediksi Kebangkrutan Altman Z-Score dan Zmijewski di BEI Periode 2011 - 2015
}

\author{
(Comparative Analysis of Altman Z-Score and Zmijewski Bankruptcy Prediction Models \\ in BEI Period 2011 - 2015)
}

\author{
Nindya Ayu Damayanti*, Nurhayati, Susanti Prasetyaningtyas \\ Jurusan Manajemen, Fakultas Ekonomi dan Bisnis, Universitas Jember (UNEJ) \\ Jln. Kalimantan 37, Jember 68121 \\ E-mail: nindyaad@gmail.com
}

\begin{abstract}
Abstrak
Penelitian ini bertujuan untuk membandingkan penggunaan model prediksi kebangkrutan Altman Z-Score dan Zmijewski pada perusahaan delisting di BEI periode 2011 - 2015. Populasi penelitian adalah perusahaan yang delisting dari BEI pada periode 2011-2015. Sampel terdiri dari 7 perusahaan dengan menggunakan metode purposive sampling. Data sekunder yang digunakan berupa laporan keuangan perusahaan yang dikeluarkan dari bursa karena bangkrut pada periode tahun 2011-2015. Analisis data pada penelitian ini adalah dengan melakukan perhitungan rasio keuangan pada masing-masing sampel penelitian, sesuai dengan variabel-variabel model prediksi kebangkrutan yang dibandingkan yaitu model Altman Z-Score dan Zmijewski. Selanjutnya mengklasifikasikan kondisi perusahaan sesuai titik cut off dari masing-masing model dan melakukan perhitungan tingkat akurasi tiap model.
\end{abstract}

Kata Kunci: Altman Z-Score, Delisting, Kebangkrutan, Zmijewski.

\begin{abstract}
This study aimed to compare the use of bankruptcy prediction model Altman Z-Score and Zmijewski on delisting companies on the Stock Exchange the period 2011 - 2015. The study population is a company delisting from the Stock Exchange in the period 2011-2015. The sample consists of 7 companies using method. purposive sampling Secondary data used in the form of financial statements of companies that issued from stock for bankruptcy in the period 2011-2015. The data analysis in this research is to perform the calculation of financial ratios in each sample, according to the variables of bankruptcy prediction model were compared to the model of Altman Z-Score and Zmijewski. Furthermore, the company classifies conditions appropriate point cut-off of each model and did calculations the accuracy of each model.
\end{abstract}

Keywords: Altman Z-Score, Delisting, Bankruptcy, Zmijewski.

\section{Pendahuluan}

Kondisi perekonomian Indonesia di tahun 2016 dinilai kurang begitu menguntungkan bagi para pengusaha lokal maupun pengusaha asing. Pertumbuhan ekonomi Indonesia pada kuartal ketiga periode Juli - September mencapai $5,02 \%$. Angka tersebut masih di bawah pertumbuhan pada kuartal sebelumnya yang mencapai $5,19 \%$. Pertumbuhan ekonomi melambat disebabkan antara lain akibat turunnya belanja pemerintah dan nilai ekspor.

Kondisi ini tentu saja mengancam perusahaan-perusahaan yang berasal dari berbagai sektor di Indonesia. Perusahaan yang tidak mampu bertahan di kondisi perekonomian yang sulit ini akan mengalami kondisi kesulitan keuangan atau bahkan bisa saja mengalami kebangkrutan. Menurut Darsono dan Ashari (2005:101), kebangkrutan adalah suatu kondisi dimana perusahaan tidak mampu membayar kewajiban keuangannya pada saat jatuh tempo. Dun dan Bradstreet (dalam Weston dan Brigham, 1991:662) menyatakan bahwa penyebab kegagalan usaha bervariasi dari situasi satu ke situasi lainnya. Sebab dari kegagalan tersebut antara lain karena manajemen yang tidak kompeten, kurang pengalaman di bidang manajerial, pengalaman tidak seimbang dalam permodalan hingga produksi, kurang pengalaman di bidang produksi yang ditangani, kelalaian, musibah, penipuan, dan alasan yang tidak diketahui.
Bursa Efek Indonesia melakukan delisting terhadap banyak perusahaan di lima tahun terakhir, yaitu tahun 2011 hingga 2015. Menurut Keputusan Direksi PT. Bursa Efek Jakarta Nomor: Kep. 308/BEJ/07/-2004 (dalam Safitri dan Fitantina, 2016), delisting adalah penghapusan efek dari daftar efek yang tercatat di bursa sehingga efek tersebut tidak dapat diperdagangkan di bursa. Perusahaan yang mengalami delisting pada tahun 2011-2015 tercatat sebanyak 20 perusahaan dan selama lima tahun terakhir perusahaan delisting terbanyak terjadi pada tahun 2013. BEI melakukan delisting terhadap 7 perusahaan pada tahun 2013 yang diawali dengan PT. Amstelco Indonesia Tbk. Alasan dilakukannya delisting karena PT. Amstelco Indonesia tidak memiliki rencana bisnis yang jelas serta tidak dapat menunjukkan indikasi pemulihan bisnis. PT. Amstelco Indonesia resmi di keluarkan dari bursa oleh BEI pada Februari 2013. Pada penghujung tahun 2013, PT. Dayaindo Resources International Tbk juga mengalami delisting setelah Otoritas BEI menerima putusan bahwa PT. Dayaindo Resources International Tbk mengalami pailit. Akhirnya emiten dengan kode saham KARK ini resmi dikeluarkan dari bursa pada 27 Desember 2013. Perusahaan mengalami delisting salah satunya disebabkan karena perusahaan tersebut mengalami kesulitan keuangan (financial distress). Kondisi kesulitan keuangan yang tidak segera diatasi bisa menyebabkan hal buruk bagi perusahaan, yaitu mengalami

\footnotetext{
* Corresponding author
} 
kebangkrutan. Kebangkrutan suatu perusahaan mampu di prediksi sebelumnya dengan menggunakan berbagai metode analisis. Salah satu analisis yang bisa dilakukan adalah analisis laporan keuangan dimana meliputi perhitungan dan interpretasi rasio keuangan.

Ada beberapa metode analisis yang menggunakan berbagai rasio keuangan untuk memprediski kebangkrutan, metode analisis tersebut diantaranya Altman Z-Score, Zmijewski, Springate, Ohlson, serta Grover. Altman Z-Score, menggunakan lima rasio keuangan yang dianggap paling berkontribusi dalam memprediksi kebangkrutan suatu perusahaan. Selain itu perusahaan juga mampu mengevaluasi kinerja keuangan dimana dari hasil penilaian kinerja tersebut dapat diidentifikasi apakah perusahaan berada dalam keadaan sehat atau terperdiksi bangkrut. Zmijewski, merupakan metode analisis yang menggunakan analisis rasio yang mengukur kinerja, leverage dan likuiditas suatu perusahaan untuk model prediksinya. Prihatini dan Sari (2013) mengemukakan bahwa, Springate merupakan metode analisis yang dikembangkan oleh Gordon LV Springate yang dibuat dengan mengikuti prosedur model Altman. Model prediksi ini menggunakan empat rasio keuangan yang dipilih dari 19 rasio keuangan yang tercantum dalam literature. Grover merupakan metode analisis yang diciptakan dengan melakukan pendesainan dan penilaian ulang terhadap model Altman Z-Score. Jefrey S. Grover menambahkan tiga belas rasio keuangan baru. Metode analisis Ohlson terinspirasi dari berbagai metode analisis financial distress sebelumnya, metode analisis yang dibangun Ohlson ini menggunakan sembilan variabel dari beberapa rasio keuangan.

Marcelinda (2013) melakukan penelitian mengenai keakuratan prediksi kebangkrutan dengan menggunakan model Altman Z-Score terhadap perusahaan manufaktur yang terdaftar BEI dan menyimpulkan bahwa model Altman ZScore memiliki tingkat akurasi sebesar 27,96 \%. Pada penelitian lain yang dilakukan oleh Yuni (2012), dimana penelitian tersebut dilakukan untuk menguji variabel-variabel rasio keuangan metode Altman Z-Score dan Zmijewski terhadap prediksi kebangkrutan perusahaan. Hasil dari penelitian tersebut menyimpulkan bahwa rasio yang mampu memprediksi kebangkrutan untuk metode Altman Z-Score adalah rasio WCTA (Working Capital to Total Assets), RETA (Retained Earning to Total Assets), MVEBVD (Market Value of Equity to Book Value of Debt) dan SATA (Sales to Total Assets) dengan tingkat akurasi sebesar 88,3\% sedangkan untuk metode Zmijewski hanya rasio leverage saja yang mampu memprediksi kebangkrutan dengan tingkat akurasi sebesar $82 \%$.

Berdasarkan penjelasan tersebut dan dari perbedaan hasil penelitian terdahulu, penulis merumuskan permasalahan sebagai berikut. Apakah model Altman Z-Score dan model Zmijewski adalah model yang tepat sebagai model prediksi kebangkrutan perusahaan delisting di BEI?

\section{Metode}

\section{Rancangan atau Desain Penelitian}

Penelitian ini merupakan penelitian deskriptif kuantitatif yaitu penelitian yang dimaksudkan untuk memberikan informasi mengenai data yang diamati agar bermakna dan komunikatif (Purwanto, 2007:109). Penelitian ini mendeskripsikan perbandingan keakuratan model prediksi kebangkrutan Altman Z-Score dan Zmijewski terhadap perusahaan delisting di BEI pada periode 2011-2015.

\section{Jenis dan Sumber Data}

Jenis data yang digunakan dalam bentuk data kuantitatif. Sumber data yang digunakan dalam penelitian ini meliputi data sekunder berupa laporan keuangan perusahaan yang dikeluarkan dari bursa karena bangkrut pada periode 20112015.

\section{Populasi dan Sampel}

Populasi untuk penelitian ini adalah semua perusahaan yang delisting di BEI pada periode 2011-2015, yaitu sebanyak 20 perusahaan. Metode pengambilan sampel menggunakan metode purposive sampling dimana metode menentukan sampel berdasarkan kriteria tertentu.

\section{Metode Analisis Data}

Analisis data dalam penelitian ini dilakukan dalam dua tahap. Tahap pertama adalah analisis untuk mendapatkan nilai dari kondisi keuangan peusahaan berdasarkan model Altman ZScore dan Zmijewski. Formula yang digunakan model Altman Z-Score adalah (Altman, 1968)

untuk perusahaan manufaktur :

$\mathrm{Z}=1,2 \mathrm{WCTA}+1,4 \mathrm{RETA}+3,3 \mathrm{EBITTA}+0,6 \mathrm{MVEBVD}+$ 0,999 SATA

untuk perusahaan non manufaktur :

$\mathrm{Z}=6,56 \mathrm{WCTA}+3,62 \mathrm{RETA}+6,72 \mathrm{EBITTA}+$ 1,05MVEBVD

Dimana:

WCTA = Working Capital/Total Assets

RETA = Retained Earnings/Total Assets

EBITTA = Earnings Before Interest and Taxes/Total Assets MVEBVD = Market Value of Equity/Book Value of Debt

SATA = Sales/Total Assets

Sedangkan formula yang digunakan untuk model Zmijewski menurut Grice dan Dugan (dalam Ladhifa, 2013) adalah

$\mathrm{X}=-4,3-4,5 \mathrm{ROA}+5,7 \mathrm{DR}-0,004 \mathrm{CR}$

Dimana :

ROA = Return On Assets (Net Income/Total Assets)

$\mathrm{DR} \quad=$ Debt Ratio (Total Liabilities/Total Assets)

$\mathrm{CR}=$ Current Ratio (Current Assets/Current Liabilities)

Tahap selanjutnya adalah membandingkan kedua model prediksi kebangkrutan untuk mengetahui persentase tingkat akurasi tiap model, persentase tingkat akurasi tiap model dihitung dengan cara membandingkan jumlah perusahaan terprediksi bangkrut dengan jumlah sampel penelitian.

\section{Hasil dan Pembahasan}

\section{Hasil}

Penelitian ini dilakukan di Bursa Efek Indonesia (BEI) dengan objek penelitian adalah perusahaan yang dikeluarkan dari Bursa Efek Indonesia periode tahun 2011-2015. Berdasarkan hasil pengumpulan data terdapat 20 perusahaan yang dikeluarkan dari bursa pada rentang waktu tahun 2011 
sampai dengan tahun 2015. Penentuan sampel penelitian menggunakan metode purposive sampling. Berdasarkan kriteria yang telah ditentukan diperoleh 7 perusahaan yang memenuhi kriteria. Detail dari daftar perusahaan yang dijadikan sampel penelitian disajikan dalam Tabel 1. sebagai berikut.

Tabel 1. Perusahaan yang Menjadi Sampel Penelitian

\begin{tabular}{|c|c|c|c|c|}
\hline No. & $\begin{array}{l}\text { Nama } \\
\text { Perusahaan }\end{array}$ & $\begin{array}{l}\text { Kode } \\
\text { Saham }\end{array}$ & $\begin{array}{l}\text { Tanggal } \\
\text { Delisting }\end{array}$ & Jenis Perusahaan \\
\hline 1 & $\begin{array}{l}\text { New Century } \\
\text { Development } \\
\text { Tbk. }\end{array}$ & PTRA & $24 / 01 / 11$ & $\begin{array}{l}\text { Non Manufaktur } \\
\text { (Property and } \\
\text { Real Estate) }\end{array}$ \\
\hline 2 & $\begin{array}{l}\text { Katarina Utama } \\
\text { Tbk. }\end{array}$ & RINA & $01 / 10 / 12$ & $\begin{array}{l}\text { Non Manufaktur } \\
\text { (Jasa) }\end{array}$ \\
\hline 3 & $\begin{array}{l}\text { Surya Intrindo } \\
\text { Makmur Tbk. }\end{array}$ & SIMM & $03 / 12 / 12$ & Manufaktur \\
\hline 4 & $\begin{array}{l}\text { Amstelco } \\
\text { Indonesia Tbk. }\end{array}$ & $\mathrm{INCF}$ & $19 / 02 / 13$ & $\begin{array}{l}\text { Non Manufaktur } \\
\text { (Keuangan) }\end{array}$ \\
\hline 5 & $\begin{array}{l}\text { Indo Setu Batu } \\
\text { Bara Resources } \\
\text { Tbk. }\end{array}$ & CPDW & $12 / 09 / 13$ & $\begin{array}{l}\text { Non Manufaktur } \\
\text { (Pertambangan) }\end{array}$ \\
\hline 6 & $\begin{array}{l}\text { Surabaya } \\
\text { Agung Industri } \\
\text { Pulp dan Kertas } \\
\text { Tbk. }\end{array}$ & SAIP & $31 / 10 / 13$ & Manufaktur \\
\hline 7 & $\begin{array}{l}\text { Asia Natural } \\
\text { Resources Tbk. }\end{array}$ & ASIA & $27 / 11 / 14$ & $\begin{array}{l}\text { Non Manufaktur } \\
\text { (Jasa) }\end{array}$ \\
\hline
\end{tabular}

Hasil analisis data pada penelitian ini adalah dengan memberikan gambaran tentang kondisi perusahaan setelah dilakukan analisis laporan keuangan berdasarkan model prediksi kebangkrutan Altman Z-Score dan Zmijewski. Selanjutnya membandingkan kedua model dah menghitung tingkat akurasi tiap model. Klasifikasi kondisi perusahaan dan perhitungan tingkat akurasi kedua model dijelaskan dalam Tabel 2. sebagai berikut

Tabel 2. Klasifikasi Kondisi Perusahaan dan Perhitungan Tingkat Akurasi Model Altman Z-Score dan Zmijewski

\begin{tabular}{|c|c|c|c|c|c|c|}
\hline $\begin{array}{l}\text { Kode } \\
\text { Sampel }\end{array}$ & $\begin{array}{l}\text { Satu Tahu } \\
\text { Altman Z } \\
\text { Score }\end{array}$ & $\begin{array}{l}\text { In Sebelum } \\
- \text { Zmijewski }\end{array}$ & $\begin{array}{l}\text { Dua Tahu } \\
\text { Altman Z } \\
\text { Score }\end{array}$ & $\begin{array}{l}\text { In Sebelum } \\
\text { Zmijewski }\end{array}$ & $\begin{array}{l}\text { Tiga Tahu } \\
\text { Altman Z } \\
\text { Score }\end{array}$ & $\begin{array}{l}\text { an Sebelum } \\
\text {-Zmijewski }\end{array}$ \\
\hline PTRA & Bangkrut & Sehat & Bangkrut & Sehat & Sehat & Bangkrut \\
\hline RINA & Sehat & Sehat & Bangkrut & Sehat & Sehat & Bangkrut \\
\hline SIMM & Bangkrut & Sehat & Bangkrut & Sehat & Bangkrut & Sehat \\
\hline INCF & Bangkrut & Sehat & Bangkrut & Sehat & Sehat & Sehat \\
\hline CPDW & Bangkrut & Bangkrut & Bangkrut & Sehat & Bangkrut & Bangkrut \\
\hline SAIP & Bangkrut & Sehat & Bangkrut & Bangkrut & Bangkrut & Bangkrut \\
\hline ASIA & Bangkrut & Bangkrut & Bangkrut & Bangkrut & Bangkrut & Bangkrut \\
\hline \multicolumn{7}{|c|}{ Keakuratan Berdasarkan Kondisi Perusahaan Delisting } \\
\hline PTRA & Benar & Salah & Benar & Salah & Salah & Benar \\
\hline RINA & Salah & Salah & Benar & Salah & Salah & Benar \\
\hline SIMM & Benar & Salah & Benar & Salah & Benar & Salah \\
\hline INCF & Benar & Salah & Benar & Salah & Salah & Salah \\
\hline CPDW & Benar & Benar & Benar & Salah & Benar & Benar \\
\hline SAIP & Benar & Salah & Benar & Benar & Benar & Benar \\
\hline ASIA & Benar & Benar & Benar & Benar & Benar & Benar \\
\hline $\begin{array}{l}\text { Jumlah } \\
\text { Benar }\end{array}$ & 7 & 2 & 8 & 2 & 4 & 5 \\
\hline $\begin{array}{l}\text { Persent } \\
\text { ase }\end{array}$ & $86 \%$ & $28,5 \%$ & $100 \%$ & $28,5 \%$ & $57 \%$ & $71,00 \%$ \\
\hline
\end{tabular}

Hasilnya pada periode tiga tahun sebelum perusahaan dikeluarkan dari bursa, model Altman Z-Score mengklasifikasikan 4 perusahaan berada pada kondisi bangkrut. Sedangkan model Zmijewski mengklasifikasikan 5 perusahaan pada kondisi bangkrut. Pada periode dua tahun sebelum perusahaan dikeluarkan dari bursa, model Altman ZScore mengklasifikasikan semua perusahaan berada pada kondisi bangkrut. Sedangkan model Zmijewski mengklasifikasikan 2 perusahaan pada kondisi bangkrut. Sedangkan untuk periode satu tahun sebelum perusahaan dikeluarkan dari bursa, model Altman Z-Score mengklasifikasikan 7 perusahaan berada pada kondisi bangkrut. Sedangkan model Zmijewski mengklasifikasikan 2 perusahaan pada kondisi bangkrut.

Persentase tingkat akurasi dihitung dengan cara membandingkan jumlah perusahaan terprediksi bangkrut dengan jumlah sampel penelitian. Untuk periode tiga tahun sebelum perusahaan dikeluarkan dari bursa, model Altman ZScore memiliki tingkat akurasi sebesar 57\% dan model Zmijewski memiliki tingkat akurasi sebesar 71\%. Sedangkan untuk periode dua tahun sebelum perusahaan dikeluarkan dari bursa, model Altman Z-Score memiliki tingkat akurasi sebesar $100 \%$ dan model Zmijewski memiliki tingkat akurasi sebesar 28,5\%. Untuk periode satu tahun sebelum perusahaan dikeluarkan dari bursa, model Altman Z-Score memiliki tingkat akurasi sebesar $86 \%$ dan model Zmijewski memiliki tingkat akurasi sebesar 28,5\%. Hal tersebut menunjukkan bahwa model Altman Z-Score lebih akurat memprediksi kebangkrutan pada periode menjelang kebangkrutan, yaitu satu tahun sebelum perusahaan dikeluarkan dari bursa. Sedangkan model Zmijewski lebih akurat memprediksi kebangkrutan pada periode tiga tahun sebelum perusahaan dikeluarkan dari bursa.

\section{Pembahasan}

Hasil penelitian menunjukkan bahwa model Altman Z-Score memiliki persentase tingkat akurasi yang tinggi pada periode satu tahun dan dua tahun sebelum perusahaan dikeluarkan dari bursa. Pada periode satu tahun sebelum dikeluarkan dari bursa, tingkat akurasi mencapai $86 \%$ dan periode dua tahun sebelum dikeluarkan dari bursa, tingkat akurasi mencapai $100 \%$. Hal tersebut karena terdapat 6 perusahaan yang memiliki aset lancar lebih rendah dibandingkan dengan hutang lancarnya dan 6 perusahaan mengalami kerugian. Hasil perhitungan ini sejalan dengan penelitian sebelumnya yaitu Yuni (2012), yang menemukan bahwa model Altman ZScore memiliki tingkat akurasi yang cukup tinggi yaitu sebesar 88,3\%. Hasil perhitungan ini berbeda dengan penilitian sebelumnya yaitu Marcelinda (2013), yang menemukan bahwa model Altman Z-Score hanya memiliki tingkat akurasi sebesar 27,96\%. Penelitian tersebut menggunakan data satu tahun sebelum perusahaan dikeluarkan dari bursa.

Model Zmijewski memiliki persentase tingkat akurasi yang cukup tinggi untuk periode tiga tahun sebelum perusahaan dikeluarkan dari bursa, yaitu sebesar $71 \%$. Hal tersebut karena terdapat 4 perusahaan yang mengalami kerugian dan 5 perusahaan yang memiliki beban utang yang melebihi total asetnya. Sedangkan tingkat akurasi model Zmijewski cukup rendah untuk periode satu dan dua tahun sebelum perusahaan dikeluarkan dari bursa, yaitu hanya sebesar 28,5\%. Hasil perhitungan ini berbeda dengan penelitian sebelumnya Yuni 
(2012) yang menemukan bahwa model Zmijewski mampu memprediksi kebangkrutan dengan tingkat keakuratan sebesar $82 \%$.

\section{Simpulan}

Model Altman Z-Score lebih akurat memprediksi kebangkrutan pada periode menjelang kebangkrutan, yaitu satu dan dua tahun sebelum perusahaan dikeluarkan dari bursa. Dengan tingkat akurasi sebesar $86 \%$ pada periode satu tahun sebelum perusahan dikeluarkan dari bursa dan !00\% pada periode dua tahun sebelum perusahaan dikeluarkan dari bursa. Sedangkan model Zmijewski lebih akurat memprediksi kebangkrutan pada periode tiga tahun sebelum perusahaan dikeluarkan dari bursa. Dengan tingkat akurasi sebesar $71 \%$ pada periode tiga tahun sebelum perusahaan dikeluarkan dari bursa.

\section{Referensi}

Altman, I. Edward. 1968. Financial Ratios, Discriminant Analysis and The Prediction of Corporate Bankruptcy. Journal of Finance, 4 (23): 589609.

Darsono, dan Ashari. 2005. Pedoman Praktis Memahami Laporan Keuangan. Edisi Kesatu. Yogyakarta: CV. ANDI OFFSET.
Ladhifa, Kurniawati. 2013. Analisis Estimasi Kebangkrutan Perusahaan dengan Pendekatan Zmijewski (X-Score) dan Altman (Z-Score) (Studi pada Industri Plastik dan Kemasan yang Terdaftar di Bursa Efek Indonesia Periode 2009-2011). Jurnal Administrasti Bisnis, 5 (1): $22-$ 29.

Marcelinda, Sheilly Olivia. 2013. Analisis Akurasi Prediksi Kebangkrutan Model Altman Z-Score pada Perusahaan Manufaktur yang Terdaftar di Bursa Efek Indonesia.Tidak Dipublikasikan. Skripsi. Jember: Universitas Jember

Prihatini, Ni Made Evi dan Maria M. Ratna Sari. 2013. Prediksi Kebankrutan dengan Model Grover, Altman Z-Score, Springate dan Zmijewski pada Perusahaan Food and Beverage di Bursa Efek Indonesia. EJurnal Akuntansi Universitas Udayana, 5(2): 417-435

Purwanto, Erwan Agus dan Dyah Ratih Sulistyastuti,. 2007. Metode Penelitian Kuantitatif untuk Administrasi Publik dan MasalahMasalah Sosial. Yogyakarta: Gava Media

Weston, J.Fred dan E.F Brigham. 1991. Essentials Of Managerial Finance. Seventh Edition: Holt Rineholt and Winston. Terjemahan oleh A.Q. Khalid. 1991. Dasar-dasar Manajemen Keuangan. Edisi ketujuh. Jilid 2. Jakarta: Erlangga.

Yuni, Lestari. 2012. Analisis Rasio Keuangan Terhadap Prediksi Kebangkrutan dengan Metode Altman dan Zmijewski pada Perusahaan Sektor Aneka Industri dan Sektor Konsumsi di Bursa Efek Indonesia. Skripsi. Jakarta: Universitas Islam Negeri Syarif Hidayatullah Jakarta. 